\title{
Analysis of Information Technology Governance In Department of Communication and Informatics of Salatiga Using COBIT 5 Framework
}

\author{
Analisis Tata Kelola Teknologi Informasi \\ Dinas Komunikasi dan Informatika Kota Salatiga \\ Menggunakan Framework COBIT 5
}

\author{
Ratna Damayanti' ${ }^{1}$, Augie David Manuputty ${ }^{2}$ \\ 1,2Information System Department, Satya Wacana Christian University, Salatiga, Indonesia \\ Email: ${ }^{1}$ ratnadamayanti877@gmail.com, 2augiemanuputty@gmail.com
}

\begin{abstract}
Technological advances and strategic environmental changes encourage the government sector to improve bureaucratic performance and services. Salatiga's Department of Communication and Informatics (Diskominfo Kota Salatiga) is a service that provides communication and informatics, statistics and coding services. However, in carrying out their duties and functions, there are still problems which indicate that the IT governance process is still not optimal, so that there is a need for identification and assessment efforts. This study aims to analyze the maturity level of IT governance using the COBIT 5 framework domain Deliver, Service and Support (DSS). The results of this study indicate that the level of capability of the DSS01, DSS03 and DSS06 processes is at level 2 (Managed process). While the DSS02 and DSS04 processes are at level 1 (Performed process). The recommendations in each process may be an input for Diskominfo in improving the quality of public services and for realizing good governance.
\end{abstract}

Keywords: IT Governance, COBIT 5, DSS Domain

\section{PENDAHULUAN}

Perkembangan Teknologi Informasi (TI) telah banyak membawa dampak di berbagai bidang baik pada organisasi swasta maupun instansi pemerintahan. Dalam sektor pemerintah, kemajuan teknologi informasi serta perubahan lingkungan strategis mendorong aparatur pemerintah untuk mengantisipasi paradigma baru dengan upaya peningkatan kinerja birokrasi serta perbaikan pelayanan kepada masyarakat.[1] Salah satu caranya adalah dengan adanya $e$ Government, sesuai dengan Peraturan Presiden Republik Indonesia Nomor 95 Tahun 2018 Tentang Sistem Pemerintahan Berbasis Elektronik (SPBE). Dalam 
hal ini, tata kelola TI menjadi aspek penting guna memastikan penerapan TI dapat selaras dengan pencapaian visi dan misi pemerintah.

Dinas Komunikasi dan Informatika (Diskominfo) Kota Salatiga merupakan lembaga pelaksana urusan pemerintah yang menjadi kewenangan daerah bidang komunikasi dan informatika, bidang statistik dan bidang persandian. Dalam penyelenggaraan tugas dan fungsi Diskominfo, ditemukan beberapa permasalahan yang berkaitan dengan pengelolaan tata kelola TI seperti : (1) Pengelolaan Sumber Daya Manusia (SDM) belum optimal, karena tugas dan fungsi pranata komputer tidak hanya berkaitan dengan TI, namun juga merangkap tugas yang lain misalnya administrasi dan bendahara dinas. Terdapat 86 orang pranata komputer yang tersebar di seluruh Organisasi Perangkat Daerah (OPD), namun hanya tersisa 25 orang pranata komputer yang masih konsisten dengan kemampuan dan keahliannya dalam bidang TI. Jumlah ini masih dirasa kurang, untuk memenuhi tugas pranata komputer dalam menyediakan pelayanan di bidang TI. (2) Belum terbentuknya service desk yang terintegrasi dengan semua perangkat daerah sehingga monitoring layanan dan penanganan masalah belum dilaksanakan secara optimal. (3) Kurangnya perhatian Diskominfo akan pentingnya pengamanan asset informasi, terbukti dengan banyaknya serangan hacker dan belum adanya master plan pengamanan sistem informasi. Berdasarkan permasalahan tersebut, perlu adanya penilaian tata kelola TI di Diskominfo untuk melihat bagaimana kondisi tata kelola TI saat ini sebagai rumusan langkah perbaikan maupun peningkatan yang dapat dilakukan.

Control Objectives for Information and related Technology (COBIT) 5 merupakan salah satu standar penilaian tata kelola TI yang dapat digunakan. COBIT 5 menyediakan pedoman yang komprehensif untuk pencapaian tujuan dan nilai organisasi melalui tata kelola dan manajemen TI yang efektif.[2] Framework COBIT 5 memberikan panduan tata kelola TI dan control objectives yang rinci bagi manajemen organisasi, stakeholder dan auditor, dengan memperhatikan aspek yang menjadi enabler tata kelola TI seperti people, services, competencies, skills, infrastructure dan applications. [3] Domain Deliver, Service and Support (DSS) berkaitan dengan pengiriman aktual serta dukungan layanan yang diperlukan, mencakup pengiriman layanan, manajemen keamanan dan kontinuitas, manajemen data dan fasilitas operasional serta dukungan layanan untuk pengguna.[4]

Penelitian ini dilakukan untuk menganalisis kondisi tata kelola TI Diskominfo Kota Salatiga menggunakan framework COBIT 5 pada domain DSS. COBIT 5 dipilih karena kerangka kerja ini menyediakan panduan yang lengkap dan rinci yang mencakup tata kelola TI organisasi dan teknik manajemen.[5] Domain DSS dipilih karena dianggap sesuai dengan kondisi TI yang ada pada Diskominfo Kota Salatiga sebagai dinas penyedia layanan TI yang telah mengimplementasikan TI dalam kegiatan operasionalnya.[6] Hasil penelitian ini 
Vol. 1, No. 2, September 2019

p-ISSN: 2656-5935 http://journal-isi.org/index.php/isi e-ISSN: 2656-4882

diharapkan dapat turut memberikan kontribusi secara akademis bagi Pemerintah Kota Salatiga khususnya Diskominfo Kota Salatiga dalam mewujudkan visi dan misi organisasi yaitu meningkatkan kualitas pelayanan publik serta mewujudkan tatakelola pemerintahan yang baik (good governance).

\section{METODOLOGI}

\subsection{Metode Pengumpulan Data}

Dalam penelitian ini digunakan pendekatan deskriptif kualitatif. Data primer diperoleh dari hasil wawancara dan diperkuat dengan data sekunder yang bersumber dari dokumen terkait yang dianalisis untuk mendapatkan gambaran lebih mengenai obyek penelitian. Obyek penelitian ditentukan berdasarkan acuan RACI chart pada COBIT 5. RACI chart merupakan matriks yang menunjukkan hubungan daftar aktivitas atau otoritas keputusan dengan pihak fungsionalitas organisasi yang terkait.[7] Ruang lingkup penelitian dibatasi pada pengukuran tingkat kapabilitas domain DSS. Hasil dari penelitian ini berupa rekomendasi yang disusun berdasarkan kondisi tata kelola TI yang ada di Diskominfo Kota Salatiga.

\subsection{Tahapan Penelitian}

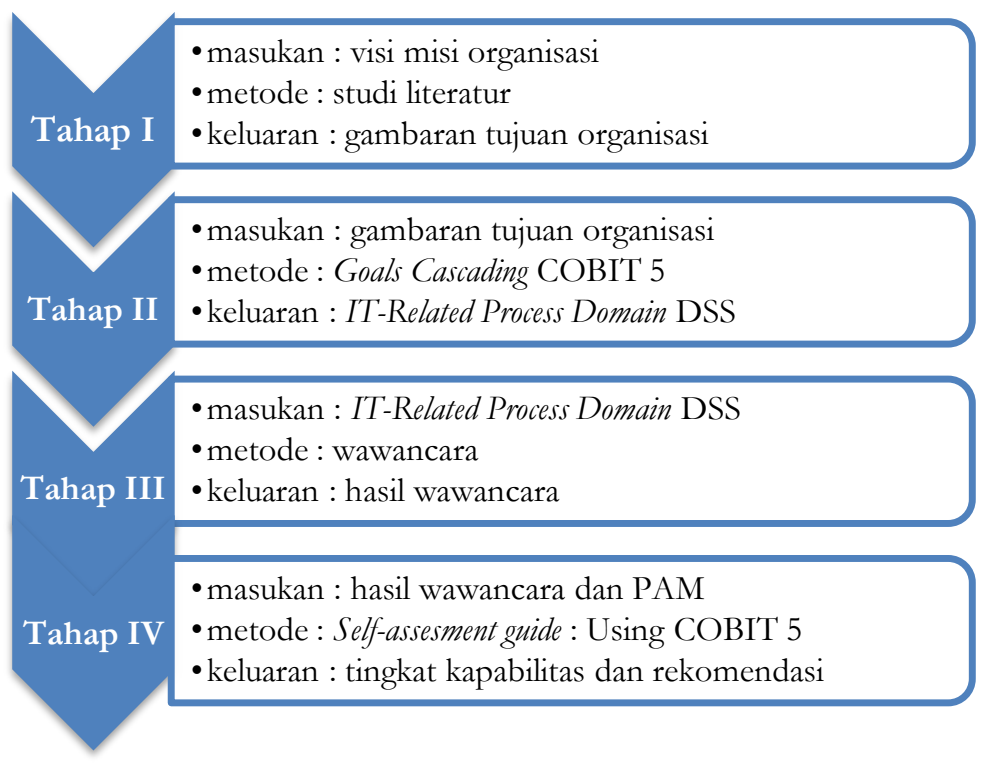

Gambar 1. Tahapan Penelitian 
Tujuan pada tahap I adalah untuk menganalisis tujuan bisnis Diskominfo Kota Salatiga. Masukan yang diperlukan adalah visi dan misi Diskominfo. Studi literatur bersumber pada dokumen Rencana Strategis Diskominfo Kota Salatiga Tahun 2017-2022 dan hasil akhir pada tahap ini yaitu gambaran tujuan Diskominfo Kota Salatiga.

Tujuan pada tahap II adalah untuk menyelaraskan tujuan bisnis organisasi dengan tujuan TI organisasi. Masukan yang diperlukan adalah tujuan Diskominfo Kota Salatiga. Pada tahap ini, dilakukan proses goals cascading yang berpedoman pada COBIT 5 framework.[8] Tujuan organisasi dipetakan ke dalam COBIT 5 Enterprise Goals (EG) dengan menggunakan 4 perspektif dari Balanced Scorecard Dimension yaitu financial, customer, internal dan learning and growth. Setelah EG terpilih, dilakukan pemetaan ke dalam IT-related Goals (ITRG).[8] ITRG yang terpilih, dipetakan lagi ke dalam IT Process berdasarkan pada COBIT 5 : Enabling Processes.[8][10]

Tujuan pada tahap III adalah untuk mendapatkan gambaran kondisi tata kelola TI yang saat ini terjadi di Diskominfo Kota Salatiga. IT Process yang telah terpilih, dijadikan acuan untuk menyusun pedoman wawancara kepada pihak-pihak terkait berdasarkan RACI charts.

Tujuan dari tahap IV adalah untuk mengetahui tingkat kapabilitas masing-masing IT Process. Proses penilaian kapabilitas berpedoman pada Self-assessment Guide : Using COBIT 5[9]. Dengan memperhatikan hasil wawancara dengan narasumber, penilaian didasarkan pada banyaknya aktivitas pada tiap-tiap management practice.[10] Setelah menentukan tingkat kapabilitas, dilakukan analisis kondisi tata kelola TI saat ini serta menyusun rekomendasi pada masing-masing proses.

\section{HASIL DAN PEMBAHASAN}

"Salatiga HATI BERIMAN yang SMART" merupakan visi Walikota Salatiga terpilih periode tahun 2017-2022. Kata HATI BERIMAN merupakan singkatan dari kata SEHAT, TERTIB, INDAH dan AMAN. Sementara itu kata SMART merupakan singkatan dari SEJAHTERA dan BERMARTABAT. Selaras dengan visi tersebut, Diskominfo Kota Salatiga berorientasikan pada visi SEJAHTERA, dimana urusan Dinas Komunikasi dan Informatika diselenggarakan dalam rangka pemenuhan layanan publik bidang pemanfaatan teknologi dan informatika serta pemenuhan kebutuhan data dan informasi masyarakat akan penyelenggaraan pemerintahan dan pembangunan. Berdasarkan rumusan misi Walikota dan Wakil Walikota Salatiga terpilih dimaksud dalam dokumen Rencana Pembangunan Jangka Menengah Daerah (RPJMD) Kota Salatiga Tahun 2017-2022 yang paling berkaitan dengan tugas 
dan fungsi Dinas Komunikasi dan Informatika adalah misi yang kesembilan, yaitu "Meningkatkan kualitas pelayanan publik dan mewujudkan tatakelola pemerintahan yang baik (good governance)".

Tujuan yang ditetapkan dalam RPJMD Tahun 2017-2022 yang ingin dicapai dalam penyelenggaraan pemerintahan daerah berdasarkan misi tersebut yang dilaksanakan oleh Dinas Komunikasi dan Informatika adalah "Meningkatkan pelaksanaan Reformasi Birokrasi pemerintah daerah dalam menunjang kualitas pelayanan publik dan tata kelola pemerintahan". Sasaran yang sesuai dengan tujuan tersebut adalah : (a) Meningkatnya kepuasan masyarakat atas pelayanan publik pada unit-unit pelayanan publik. (b) Meningkatnya keterbukaan informasi publik dan penerapan teknologi informasi dalam penyelenggaraan pemerintahan. Dalam Rencana Strategis (Renstra) Diskominfo periode 2017-2022, tujuan tersebut dijabarkan kembali secara lebih rinci seperti tercantum dalam tabel 1.

Tabel 1. Tujuan dan Sasaran Diskominfo

\begin{tabular}{|c|c|}
\hline Tujuan & Sasaran \\
\hline $\begin{array}{l}\text { Pemenuhan kebutuhan } \\
\text { pendukung pelayanan } \\
\text { untuk meningkatkan } \\
\text { kinerja perangkat daerah. }\end{array}$ & $\begin{array}{l}\text { - Terpenuhinya sarana dan prasarana untuk } \\
\text { menunjang kinerja pelayanan. } \\
\text { - } \text { Terpenuhinya administrasi perkantoran. } \\
\text { - } \quad \text { Meningkatnya disiplin Aparatur Sipil } \\
\text { Negara (ASN) } \\
\text { - Terpenuhinya SDM sesuai dengan kualitas } \\
\text { dan kuantitas yang dibutuhkan. }\end{array}$ \\
\hline $\begin{array}{l}\text { Penyediaan kebijakan di } \\
\text { bidang komunikasi } \\
\text { informasi, bidang statistik, } \\
\text { tata kelola e-goverment. }\end{array}$ & $\begin{array}{l}\text { Tersedianya kebijakan di bidang } \\
\text { komunikasi. informasi, statistik, } \\
\text { persandian dan bidang tata kelola e- } \\
\text { government. }\end{array}$ \\
\hline $\begin{array}{l}\text { Peningkatan } \\
\text { kinerjapelayanan } \\
\text { komunikasi dan informasi. }\end{array}$ & $\begin{array}{l}\text { - Terbentuknya KIM (Kelompok Informasi } \\
\text { Masyarakat) di Kota Salatiga. } \\
\text { - Terbentuknya FK-METRA (Forum } \\
\text { Komunikasi Media Tradisional) di } \\
\text { tingkat kota. } \\
\text { - Terbangunnya website di SKPD dan } \\
\text { Kelurahan. }\end{array}$ \\
\hline $\begin{array}{l}\text { Peningkatan pelayanan } e_{-} \\
\text {government. }\end{array}$ & $\begin{array}{l}\text { - Terlaksananya penyelenggaraan pelayanan } \\
\text { e-government sesuai dengan regulasi. }\end{array}$ \\
\hline $\begin{array}{l}\text { Penyediaan \& pengelolaan } \\
\text { data statistik sektoral. }\end{array}$ & $\begin{array}{ll}\text { - } & \text { Tersedianya data statistik sektoral. } \\
\text { - } & \text { Terbangunnya Single Data System (Sistem }\end{array}$ \\
\hline
\end{tabular}


Vol. 1, No. 2, September 2019

\begin{tabular}{|c|c|}
\hline \multirow[t]{2}{*}{ p-ISSN: 2656-5935 } & urnal-isi.org/index.php/isi \\
\hline & Satu Data) \\
\hline $\begin{array}{l}\text { Peningkatan } \\
\text { penyelenggaraan }\end{array}$ & $\begin{array}{l}\text { - Terjaminnya keamanan data/informasi } \\
\text { daerah }\end{array}$ \\
\hline $\begin{array}{l}\text { persandian untuk } \\
\text { pengamanan informasi } \\
\text { daerah. }\end{array}$ & $\begin{array}{l}\text { - Terpenuhinya sarana dan prasarana } \\
\text { penyelenggaraan persandian untuk } \\
\text { keamanan data / informasi daerah. }\end{array}$ \\
\hline $\begin{array}{l}\text { Peningkatan pola } \\
\text { hubungan komunikasi } \\
\text { sandi antar perangkat } \\
\text { daerah. }\end{array}$ & $\begin{array}{l}\text { - Meningkatnya jumlah perangkat daerah } \\
\text { yang menggunakan sandi dalam hubungan } \\
\text { komunikasi. }\end{array}$ \\
\hline
\end{tabular}

Tujuan dan sasaran dari Diskominfo Kota Salatiga dipetakan ke dalam COBIT 5 Enterprise Goals dengan memperhatikan perspektif dari IT Balanced Scorecard. Pemetaan tersebut ditunjukan pada tabel 2.

Tabel 2. Pemetaan Enterprise Goals dengan tujuan organisasi

\begin{tabular}{|c|c|c|c|}
\hline $\begin{array}{l}\text { Perspektif } \\
\text { IT BSC }\end{array}$ & Kode & $\begin{array}{c}\text { COBIT } 5 \\
\text { Enterprise } \\
\text { Goals }\end{array}$ & Tujuan Bisnis Diskominfo \\
\hline \multirow[t]{2}{*}{ Financial } & EG05 & $\begin{array}{l}\text { Financial } \\
\text { transparency }\end{array}$ & $\begin{array}{l}\text { Meningkatkan kualitas pelayanan publik } \\
\text { dan mewujudkan tatakelola }\end{array}$ \\
\hline & & & $\begin{array}{l}\text { pemerintahan yang baik (good } \\
\text { governance). Melalui konsep good } \\
\text { governance ini pembangunan daerah dan } \\
\text { pengelolaan sektor publik dilakukan } \\
\text { dengan berbasis pada partisipasi, } \\
\text { transparansi dan akuntabilitas. }\end{array}$ \\
\hline Customer & EG06 & $\begin{array}{l}\text { Customer- } \\
\text { oriented } \\
\text { service culture }\end{array}$ & $\begin{array}{l}\text { Meningkatnya kepuasan masyarakat } \\
\text { atas pelayanan publik pada unit-unit } \\
\text { pelayanan publik }\end{array}$ \\
\hline Internal & EG14 & $\begin{array}{l}\text { Operational } \\
\text { and staff } \\
\text { productivity }\end{array}$ & $\begin{array}{l}\text { Terlaksananya penyelenggaraan } \\
\text { pelayanan e-government sesuai dengan } \\
\text { regulasi, dengan strategi : Peningkatan } \\
\text { efektifitas kinerja dan tertib administrasi } \\
\text { melalui penyediaan regulasi kebijakan } \\
\text { dan penyusunan SOP. }\end{array}$ \\
\hline $\begin{array}{l}\text { Learning \& } \\
\text { Growth }\end{array}$ & EG16 & $\begin{array}{l}\text { Skilled and } \\
\text { motivated }\end{array}$ & $\begin{array}{l}\text { Terpenuhinya SDM sesuai dengan } \\
\text { kualitas dan kuantitas yang dibutuhkan, }\end{array}$ \\
\hline
\end{tabular}


Vol. 1, No. 2, September 2019

p-ISSN: 2656-5935 http://journal-isi.org/index.php/isi e-ISSN: 2656-4882

$\begin{array}{ll}\text { people } & \text { dengan strategi : } \\ & \text { Meningkatkan kapasitas dan kompetensi } \\ \text { SDM melalui diklat, bintek dan } \\ \text { workshop. }\end{array}$

COBIT 5 Enterprise Goals yang telah terpilih kemudian dipetakan dengan ITrelated goals (ITRG). ITRG yang dipilih hanya yang memiliki keterkaitan kuat (Primary). Hasil Pemetaan ditunjukkan pada tabel 3 dan deskripsi masing-masing ITRG terpilih ditunjukkan pada tabel 4.

Tabel 3. Pemetaan enterprise goals dengan IT-related goals

\begin{tabular}{ll}
\hline EG Terpilih & ITRG (Primary) \\
\hline EG05 & ITRG06 \\
EG06 & ITRG01, ITRG07 \\
EG14 & ITRG08, ITRG16 \\
EG16 & ITRG16 \\
\hline
\end{tabular}

Tabel 4. Deskripsi ITRG terpilih

\begin{tabular}{cl}
\hline Kode & \multicolumn{1}{c}{ Deskripsi } \\
\hline ITRG01 & Alignment of IT and business strategy \\
ITRG06 & Transparency of IT costs, benefits and risk \\
ITRG07 & Delivery of IT services in line with business requirements \\
ITRG08 & Adequate use of applications, information and technology solutions \\
ITRG16 & Competent and motivated business and IT personnel \\
\hline
\end{tabular}

ITRG yang telah terpilih kemudian dipetakan lagi dengan IT process. Pemetaan ini dilakukan untuk mendapatkan proses-proses TI pada COBIT khususnya domain DSS yang memiliki keterkaitan dengan tujuan bisnis dan tujuan IT organisasi. Tabel 5 menunjukkan hasil pemetaan ITRG terpilih dengan IT process, deskripsi pada masing-masing IT process ditunjukkan pada tabel 6.

Tabel 5. Pemetaan IT-related goals dengan IT Process

\begin{tabular}{cl}
\hline ITRG & \multicolumn{1}{c}{ IT Process } \\
\hline ITRG01 & $\begin{array}{l}\text { EDM01, EDM02, APO01, APO02, APO03, APO05, APO07, } \\
\text { APO08, BAI01, BAI02 }\end{array}$
\end{tabular}


Vol. 1, No. 2, September 2019

\begin{tabular}{|c|c|c|c|}
\hline \multicolumn{2}{|c|}{ p-ISSN: 2656-5935 } & http://journal-isi.org/index.php/isi & e-ISSN: $2656-4882$ \\
\hline ITRG06 & \multicolumn{3}{|c|}{ EDM02, EDM03, EDM05, APO06, APO12, APO13, BAI09 } \\
\hline ITRG07 & \multicolumn{3}{|c|}{$\begin{array}{l}\text { EDM01, EDM02, EDM05, APO02, APO08, APO09, APO10, } \\
\text { APO11, BAI02, BAI03, BAI04, BAI06, DSS01, DSS02, DSS03, } \\
\text { DSS04, DSS06, MEA01 }\end{array}$} \\
\hline ITRG08 & \multicolumn{3}{|c|}{ APO04, BAI05, BAI07 } \\
\hline ITRG16 & \multicolumn{3}{|c|}{ EDM04, APO01, APO07 } \\
\hline
\end{tabular}

Tabel 6. Deskripsi IT Process domain DSS

\begin{tabular}{ll}
\hline \multicolumn{1}{c}{ Kode } & \multicolumn{1}{c}{ Deskripsi } \\
\hline DSS01 & Manage Operations \\
DSS02 & Manage Service Requests and Incidents \\
DSS03 & Manage Problems \\
DSS04 & Manage Continuity \\
DSS06 & Manage Business Process Controls \\
\hline
\end{tabular}

Untuk mendapatkan informasi mengenai kondisi tata kelola Diskominfo Kota Salatiga, wawancara dilakukan dengan narasumber terkait yang terdapat dalam RACI chart, seperti ditunjukkan pada tabel 7.

Tabel 7. RACI chart [11]

\begin{tabular}{cll}
\hline RACI & \multicolumn{1}{c}{ Fungsi dan Peran } & \multicolumn{1}{c}{ Fungsionalitas Organisasi } \\
\hline Responsible & Bertanggungjawab & - Bidang Aplikasi Informatika \\
& melaksanakan dan & - Bidang Informasi dan Komunikasi \\
& menyelesaikan aktivitas & Publik \\
& yang menjadi tanggung & \\
& jawabnya. & \\
Accountable & Mengarahkan jalannya & - Kepala Diskominfo Kota Salatiga \\
& pelaksanaan aktivitas. & \\
Consulted & Memberikan pendapat atau & - Kepala Diskominfo Kota Salatiga \\
& tempat konsultasi & \\
& pelaksanaan aktivitas. & \\
Mnformed & Mendapat informasi & - Seksi Layanan Data dan Informasi \\
& mengenai pelaksanaan & - Seksi Jejaring Komunikasi Publik \\
& aktivitas. & - Seksi Infrastruktur \\
& & - Seksi Sistem Informasi \\
\hline
\end{tabular}


Vol. 1, No. 2, September 2019

p-ISSN: 2656-5935 http://journal-isi.org/index.php/isi e-ISSN: 2656-4882

\section{Domain DSS01 - Manage Operations}

Berdasarkan penilaian pada self-assesment guide COBIT 5, proses manajemen operasional mencapai level 2 managed process dengan skala nilai partially achieved. Tujuan yang diharapkan pada proses ini adalah (1) kegiatan operasional dilakukan sesuai keperluan dan terjadwal; (2) kegiatan operasional dimonitor, diukur, dilaporkan dan diperbaiki.

Tabel 8. Pencapaian Kapabilitas DSS01

\begin{tabular}{|l|c|c|c|c|c|c|c|c|c|c|}
\hline $\begin{array}{c}\text { Process } \\
\text { Name }\end{array}$ & Level 0 & Level 1 & \multicolumn{2}{|c|}{ Level 2 } & \multicolumn{2}{|c|}{ Level 3 } & \multicolumn{2}{c|}{ Level 4 } & \multicolumn{2}{c|}{ Level 5 } \\
\hline DSS01 & & PA & PA & PA & PA & PA & PA & PA & PA & PA \\
1.1 & 2.1 & 2.2 & 3.1 & 3.2 & 4.1 & 4.2 & 5.1 & 5.2 \\
\hline $\begin{array}{l}\text { Rating by } \\
\text { Criteria }\end{array}$ & F & F & F & P & & & & & & \\
\hline $\begin{array}{l}\text { Capability } \\
\text { Level } \\
\text { Achieved }\end{array}$ & & & 2 & & & & & & & \\
\hline
\end{tabular}

Kegiatan operasional masing-masing bidang di Diskominfo telah diatur dalam Standar Operasional Prosedur (SOP) Pengelolaan Informasi dan Dokumentasi Publik di Lingkungan Pemerintah Kota Salatiga berdasarkan Keputusan Kepala Dinas Komunikasi dan Informatika Kota Salatiga Nomor 060/11/412/2017. Tugas serta fungsi masing-masing bagian juga telah dirumuskan dalam Tugas Pokok dan Fungsi (Tupoksi) Diskominfo Kota Salatiga. Infrastruktur TI sudah sesuai dengan kebutuhan diskominfo, namun proses monitoringnya belum dilakukan secara optimal, seperti yang disampaikan Bapak Fara Mustofa selaku Kepala Seksi Sistem Informasi :

“... Kalau insiden yang berkaitan dengan infrastruktur TI belum tercatat, sini kan kelemahannya belum ada service desk. Kalau belum ada service desk kan kita belum bisa mencatat, contohnya keluhan, misal internet mati itu setahun berapa kali. Karena belum ada service desk, jadi lapornya langsung ke teknisi, nah kan teknisi sibuk kadang nggak mencatat juga"

Diskominfo sudah memperhatikan penempatan dan pemodelan fasilitas TI untuk meminimalkan kerentanan ancaman lingkungan, namun belum ada perangkat yang secara proaktif mendeteksi ancaman lingkungan, hanya terdapat APAR sebagai pertolongan pertama saat terjadi kebakaran, serta belum pernah ada pelatihan pegawai atas prosedur tanggap darurat jika terdapat pemberitahuan bencana. 
Vol. 1, No. 2, September 2019

p-ISSN: 2656-5935 http://journal-isi.org/index.php/is

e-ISSN: 2656-4882

Berdasarkan kondisi existing tersebut, rekomendasi yang diberikan adalah menyusun kebijakan dan standar pedoman pengelolaan operasional TI secara rinci dan menyeluruh, mencangkup aspek proses (SOP), aspek layanan TI dengan pihak ketiga, aspek infrastruktur dan fasilitas TI, aspek lingkungan TI serta aspek sistem informasi. Service desk juga diperlukan segera, supaya aktivitas yang dilakukan dapat dimonitor dengan lebih baik.

\section{Domain DSS02 - Manage Service Requests and Incidents}

Berdasarkan penilaian pada self-assesment guide COBIT 5, proses manajemen permintaan layanan dan insiden mencapai level 1 performed process dengan skala nilai fully achieved. Tujuan yang diharapkan pada proses ini adalah (1) Layanan terkait TI dapat digunakan; (2) Insiden diselesaikan berdasarkan tingkat layanan yang disepakati; (3) Permintaan layanan ditangani sesuai dengan tingkat layanan yang disepakati dan untuk kepuasan pengguna.

Tabel 9. Pencapaian Kapabilitas DSS02

\begin{tabular}{|c|c|c|c|c|c|c|c|c|c|c|}
\hline $\begin{array}{l}\text { Process } \\
\text { Name }\end{array}$ & $\begin{array}{c}\text { Level } \\
0\end{array}$ & $\begin{array}{c}\text { Level } \\
1\end{array}$ & \multicolumn{2}{|c|}{ Level 2} & \multicolumn{2}{|c|}{ Level 3} & \multicolumn{2}{|c|}{ Level 4} & \multicolumn{2}{|c|}{ Level 5} \\
\hline DSS02 & & $\begin{array}{l}\text { PA } \\
1.1\end{array}$ & $\begin{array}{l}\text { PA } \\
2.1\end{array}$ & $\begin{array}{l}\text { PA } \\
2.2\end{array}$ & $\begin{array}{l}\text { PA } \\
3.1\end{array}$ & $\begin{array}{l}\text { PA } \\
3.2\end{array}$ & $\begin{array}{l}\text { PA } \\
4.1\end{array}$ & $\begin{array}{l}\text { PA } \\
4.2\end{array}$ & $\begin{array}{l}\text { PA } \\
5.1\end{array}$ & $\begin{array}{l}\mathrm{PA} \\
5.2\end{array}$ \\
\hline $\begin{array}{l}\text { Rating by } \\
\text { Criteria }\end{array}$ & $\mathrm{F}$ & $\mathrm{F}$ & P & & & & & & & \\
\hline $\begin{array}{l}\text { Capability } \\
\text { Level } \\
\text { Achieved }\end{array}$ & & 1 & & & & & & & & \\
\hline
\end{tabular}

Layanan yang diberikan diskominfo yaitu : (1) Layanan Pejabat Pengelola Informasi dan Dokumentasi (PPID); (2) Layanan Kemitraan Media Pembinaan Komunitas KIM; (3) Layanan Subdomain, Email, Hosting dan Collaction Server SKPD; (4) Layanan Pengembangan SDM TIK; (4) Layanan Internet Wifi; (5) Layanan Statistik Sektoral. Pengelolaan layanan sudah dilakukan dengan baik dan sistematis.

“... Kalau model dan alur permohonan sudah ada, SOP kita itu mengikuti peraturan Komisi Informasi No. 01 tahun 2010 tentang permohonan layanan informasi, jadi kita tinggal mengadopsi”.

Dari penjelasan dari Bapak Andi Fauzan Arifianto selaku Kepala Seksi Layanan Data dan Informasi, diskominfo telah menetapkan skema 
Vol. 1, No. 2, September 2019

p-ISSN: 2656-5935 http://journal-isi.org/index.php/isi e-ISSN: 2656-4882

permintaan layanan. Daftar permintaan sudah otomatis tercatat dalam aplikasi web yang digunakan, namun tidak terdapat kategori khusus sebagai acuan prioritas layanan.

"Kita nggak ada prioritas, karena di Undang-undang keterbukaan informasi publik itu kan permohonan informasi sudah jelas aturannya, dalam 10 bari kerja harus diselesaikan, kalau dalam 10 hari kerja belum bisa diselesaikan, bisa ditambah lagi 7 hari kerja. Jadi semuanya tidak ada prioritas, artinya ketika ada permohonan masuk ya prosedur penanganannya harus seperti itu”.

Saat terjadi insiden, sudah ada upaya untuk menganalisis dan mengidentifikasi penyebab masalah, namun saat ini belum terdapat aturan atau prosedur yang mengatur insiden keamanan yang mungkin terjadi. Terdapat upaya untuk melacak, menganalisis dan melaporkan kejadian yang telah ditangani, namun hal ini belum dilakukan secara rutin.

Berdasarkan kondisi existing tersebut, rekomendasi yang diberikan adalah menyusun kebijakan atau prosedur mengenai insiden yang mungkin terjadi. Upaya analisis dan pelaporan atas layanan dan insiden sebaiknya dilakukan secara rutin supaya didapat informasi sebagai bahan untuk perbaikan berkelanjutan.

\section{Domain DSS03 - Manage Problems}

Berdasarkan penilaian pada self-assesment guide COBIT 5, proses manajemen masalah mencapai level 2 managed process dengan skala nilai partially achieved. Tujuan yang diharapkan pada proses ini adalah masalah terkait TI dapat diselesaikan sehingga tidak terulang kembali.

Tabel 10. Pencapaian Kapabilitas DSS03

\begin{tabular}{|c|c|c|c|c|c|c|c|c|c|c|}
\hline $\begin{array}{l}\text { Process } \\
\text { Name }\end{array}$ & $\begin{array}{c}\text { Level } \\
0\end{array}$ & $\begin{array}{c}\text { Level } \\
1\end{array}$ & \multicolumn{2}{|c|}{ Level 2} & \multicolumn{2}{|c|}{ Level 3} & \multicolumn{2}{|c|}{ Level 4} & \multicolumn{2}{|c|}{ Level 5} \\
\hline & & $\mathrm{PA}$ & PA & PA & PA & $\mathrm{PA}$ & PA & PA & PA & PA \\
\hline DSSOS & & 1.1 & 2.1 & 2.2 & 3.1 & 3.2 & 4.1 & 4.2 & 5.1 & 5.2 \\
\hline $\begin{array}{l}\text { Rating by } \\
\text { Criteria }\end{array}$ & $\mathrm{F}$ & $\mathrm{F}$ & $\mathrm{F}$ & P & & & & & & \\
\hline $\begin{array}{l}\text { Capability } \\
\text { Level } \\
\text { Achieved }\end{array}$ & & & 2 & & & & & & & \\
\hline
\end{tabular}


Manajemen permasalahan yang ada di diskominfo sudah berjalan dengan baik, masalah sudah diidentifikasi dan dikategorikan, misalnya permasalahan terkait pengelolaan web SKPD, permasalahan aplikasi dan permasalahan terkait jaringan. Sudah terdapat pula kelompok pendukung yang membantu mengidentifikasi masalah, menganalisis akar masalah, dan penentuan solusi untuk mendukung manajemen masalah. Tiap-tiap bidang kegiatan sudah dibagi tugasnya dan sudah ada staf teknik sebagai penanggungjawab. Namun saat ini diskominfo belum memiliki laporan kejadian/pencatatan secara sistem atas masalah TI, karena belum adanya service desk, pencatatan hanya dilakukan secara pribadi oleh pegawai yang menangani masalah tersebut, seperti yang disampaikan oleh Bapak Fara Mustofa berikut :

“... secara sistem, permasalahan kita belum tercatat, hanya secara perorangan di tiap-tiap petugasnya pasti mencatat, karena itu masuk ke butir kegiatan harian. Tapi kalau secara sistem service desk nya, kita belum punya, makanya kita mencatat".

Monitoring proses penanganan masalah dilakukan secara lisan baik secara individu maupun kelompok. Penyampaian kelompok dilakukan pada saat staff meeting yang dilakukan tiap bulan. Laporan daftar masalah, identifikasi akar permasalahan dan solusi dilakukan secara manual oleh masing-masing pegawai yang bersangkutan. Untuk kegiatan monitoring dan pelaporan masalah secara sistem belum terlaksana karena belum adanya service desk. Solusi atau manajemen masalah yang dilakukan belum bersifat proaktif. Masalah yang terjadi belum tercatat secara menyeluruh dan belum diketahui hubungan suatu permasalahan dengan permasalahan yang lain, sehingga belum dapat dirumuskan solusi kedepannya yang bersifat proaktif untuk mengantisipasi permasalahan yang sama.

Berdasarkan kondisi existing tersebut, rekomendasi yang diberikan adalah membentuk service desk sebagai wadah pusat pencatatan aktivitas layanan TI dan penanganan masalah atau insiden. Setelah dibentuknya service desk, sebaiknya dilakukan pula peninjauan masalah secara rutin dan berkala, guna merumuskan kebijakan atau solusi yang bersifat proaktif.

\section{Domain DSS04 - Manage Continuity}

Berdasarkan penilaian pada self-assesment guide COBIT 5, proses manajemen kontinuitas mencapai level 1 performed process dengan skala nilai largely achieved. Tujuan yang diharapkan pada proses ini adalah (1) Informasi penting bisnis tersedia untuk bisnis sejalan dengan tingkat layanan minimum yang disyaratkan; (2) Ketahanan yang memadai tersedia untuk layanan kritis; (3) Tes kesinambungan layanan telah memverifikasi efektivitas rencana; (4) Rencana 
Vol. 1, No. 2, September 2019

p-ISSN: 2656-5935 http://journal-isi.org/index.php/isi e-ISSN: 2656-4882

kesinambungan yang up-to-date mencerminkan persyaratan bisnis saat ini; (5) Pihak internal dan eksternal telah dilatih dalam rencana kesinambungan.

Tabel 11. Pencapaian Kapabilitas DSS04

\begin{tabular}{|l|c|c|c|c|c|c|c|c|c|c|}
\hline \multicolumn{1}{|c|}{$\begin{array}{c}\text { Process } \\
\text { Name }\end{array}$} & $\begin{array}{c}\text { Level } \\
0\end{array}$ & $\begin{array}{c}\text { Level } \\
1\end{array}$ & \multicolumn{2}{|c|}{ Level 2 } & \multicolumn{2}{c|}{ Level 3 } & \multicolumn{2}{c|}{ Level 4 } & \multicolumn{2}{c|}{ Level 5 } \\
\hline DSS04 & & PA & PA & PA & PA & PA & PA & PA & PA & PA \\
1.1 & 2.1 & 2.2 & 3.1 & 3.2 & 4.1 & 4.2 & 5.1 & 5.2 \\
\hline $\begin{array}{l}\text { Rating by } \\
\text { Criteria }\end{array}$ & F & L & & & & & & & & \\
\hline $\begin{array}{l}\text { Capability } \\
\text { Level } \\
\text { Achieved }\end{array}$ & & 1 & & & & & & & & \\
\hline
\end{tabular}

Perencanaan keberlangsungan bisnis diskominfo didefinisikan dalam Renstra Diskominfo Kota Salatiga Tahun 2017-2022 khususnya bagian strategi dan kebijakan. Dalam memanajemen kontinuitas bisnis atau layanan, terlebih ketika terjadi masalah atau gangguan, diskominfo turut melibatkan stakeholder terkait, seperti yang disampaikan oleh Bapak Muh Nasiruddin selaku Kepala Diskominfo Kota Salatiga berikut :

“... kemudian ketika ada gangguan, otomatis kita akan kembali ke renstra, apa yang kita laksanakan. Ketika terjadi gangguan, seluruh stakeholder yang terkait harus kita ajak berdiskusi bersama, jadi semua stakeholder yang terkait itu tau, baik itu intern kominfo maupun yang berada di luar kominfo".

Saat ini belum terdapat pengujian dan review rencana kesinambungan bisnis diskominfo, namun review terhadap kegiatan proses bisnis sudah terlaksana. Setiap bulan terdapat kegiatan Pengendalian Organisasi Kegiatan (POK), setiap bulan terdapat rapat yang dihadiri masing-masing bidang untuk melakukan evaluasi kerja dan menyampaikan kendala yang dihadapi.

Berdasarkan kondisi existing tersebut, rekomendasi yang diberikan adalah penyusunan Business Continuity Plan (BCP) yang meliputi penentuan lingkup dan rencana serta Business Impact Analysis (BIA). Diskominfo juga sebaiknya menyusun Disaster Recovery Plan (DRP) yang meliputi proses, pengujian dan prosedur rencana pemulihan bencana.

\section{Domain DSS06 - Manage Business Process Controls}

Berdasarkan penilaian pada self-assesment guide COBIT 5, proses manajemen kontrol proses bisnis mencapai level 2 managed process dengan skala nilai partially 
Vol. 1, No. 2, September 2019

p-ISSN: 2656-5935 http://journal-isi.org/index.php/isi

e-ISSN: 2656-4882

achieved. Tujuan yang diharapkan pada proses ini adalah (1) Cakupan dan efektivitas kontrol utama untuk memenuhi persyaratan bisnis untuk memproses informasi sudah lengkap; (2) Inventarisasi peran, tanggung jawab, dan hak akses selaras dengan kebutuhan bisnis yang sah; (3) Transaksi bisnis dipertahankan sepenuhnya dan sebagaimana disyaratkan dalam log.

Tabel 12. Pencapaian Kapabilitas DSS06

\begin{tabular}{|l|c|c|c|c|c|c|c|c|c|c|}
\hline \multicolumn{1}{|c|}{$\begin{array}{c}\text { Process } \\
\text { Name }\end{array}$} & $\begin{array}{c}\text { Level } \\
0\end{array}$ & $\begin{array}{c}\text { Level } \\
1\end{array}$ & \multicolumn{2}{|c|}{ Level 2 } & \multicolumn{2}{|c|}{ Level 3 } & \multicolumn{2}{|c|}{ Level 4 } & \multicolumn{2}{|c|}{ Level 5 } \\
\hline DSS06 & & PA & PA & PA & PA & PA & PA & PA & PA & PA \\
1.1 & 2.1 & 2.2 & 3.1 & 3.2 & 4.1 & 4.2 & 5.1 & 5.2 \\
\hline $\begin{array}{l}\text { Rating by } \\
\text { Criteria }\end{array}$ & F & F & F & P & & & & & & \\
\hline $\begin{array}{l}\text { Capability } \\
\text { Level } \\
\text { Achieved }\end{array}$ & & & 2 & & & & & & & \\
\hline
\end{tabular}

Secara regulatif, proses kebijakan tentang aktivitas kontrol di diskominfo belum selesai, namun realisasinya sudah dilakukan. Aktivitas kontrol yang ada pada proses bisnis sudah selaras dengan tujuan diskominfo. Pemantauan atas kegiatan proses bisnis dan aktivitas kontrol dilakukan dengan melihat SOP sebagai salah satu acuannya. Di dalam SOP juga sudah tercantum peran, tanggungjawab, hak akses dan tingkat otoritas pegawai.

"Di Kominfo itu setiap hari ada sekitar 200 serangan terhadap sistem informasi yang kita bangun. Inilah yang baru kita rasakan sekarang, betapa pentingnya pengamanan sistem informasi. Kita mudah membangun sistem informasi, namun kita jarang bepikiran bagaimana cara mengamankan informasi yang kita miliki. Pada tabun ini, baru kita berpikir bagaimana tata kelola pengamanan sistem informasi”.

Berdasarkan keterangan dari Bapak Muh Nasiruddin, kontrol terhadap pengamanan asset informasi di Diskominfo masih kurang. Sebagai solusinya, saat ini Diskominfo bekerjasama dengan Badan Siber dan Sandi Negara (BSSN) dan Balai Sertifikasi Elektronik (BSrE) untuk pengamanan asset informasi pada 3 OPD, yaitu Diskominfo, Keuangan dan Kepegawaian.

Berdasarkan kondisi existing tersebut, rekomendasi yang diberikan adalah meninjau dan mengevaluasi prosedur keamanan yang sudah ada, khususnya prosedur yang berkaitan dengan pengamanan asset informasi. Kebijakan mengenai aktivitas kontrol juga sebaiknya segera diselesaikan, serta perlu adanya 
pencatatan atau dokumentasi atas pemantauan kegiatan proses bisnis dan aktivitas kontrol.

\section{KESIMPULAN}

Berdasarkan hasil analisis menggunakan Process Assessment Model (PAM) COBIT 5, diketahui bahwa proses DSS01, DSS03 dan DSS06 berada pada level 2 (Managed process). Hal ini menunjukkan bahwa sebagian proses tata kelola TI pada Diskominfo Kota Salatiga sudah diimplementasikan dan terkelola, mulai dari perencanaan, pemantauan dan koordinasi yang baik serta hasil dari proses ini sudah ditetapkan, dikendalikan dan dipelihara secara tepat. Proses DSS02 dan DSS04 berada pada level 1 (Performed process), yang berarti tujuan dari proses sudah tercapai. Diskominfo Kota Salatiga telah menyadari pentingnya pengelolaan TI dalam proses bisnis,terbukti dari operasional dan layanan TI sudah dilakukan dan dimonitor dengan baik, Meskipun begitu, Diskominfo harus selalu melakukan perbaikan dan peningkatan pelayanan.Oleh karena itu, diberikan beberapa rekomendasi yang diharapkan dapat membantu memaksimalkan proses implementasi tata kelola TI di Diskominfo Kota Salatiga.

\section{DAFTAR PUSTAKA}

[1] Sa'diyah, Ulfa \& Manuputty, Augie D, "Analisa Tata Kelola EGovernment Pemerintah Kota Salatiga Menggunakan Framework COBIT 5 Domain APO," Seminar Nasional Teknologi Informasi dan Komunikasi 2018 (SENTIKA 2018) Yogyakarta, 2017.

[2] Candra, Rio Kurnia, “Audit Teknologi Informasi menggunakan Framework COBIT 5 Pada Domain DSS (Delivery, Service, and Support) (Studi Kasus : iGracias Telkom University)," e-Proceeding of Engineering : Vol.2, No.1 April 2015 Page 11-29, 2015.

[3] Agoan, Tedi S, “Analisa Tingkat Kematangan Teknologi Informasi Pada Dinas Komunikasi Dan Informatika Kota Manado Menggunakan Framework COBIT 5 Domain Evaluate, Direct, Monitor (EDM) dan Deliver, Service, and Support (DSS)," E-Journal Teknik Informatika Vol 10, No.1 (2017) ISSN: 2301-8364, 2017.

[4] Cahyani, Ulfatisa., Ismiarta A., dan Andi R.P., "Evaluasi Layanan BPJSTK Mobile Dengan Menggunakan Domain Deliver, Service and Support Berdasarkan Framework COBIT 5 (Studi Kasus : BPJS Ketenagakerjaan Cabang Mataram)," Jurnal Pengembangan Teknologi Informasi dan Ilmu Komputer Vol. 2, No. 8, Agustus 2018, hlm. 2382-2391, 2018. 
[5] Gondodiyoto, Sanyoto, "Audit Sistem Informasi + Pendekatan CobIT" Jakarta:Mitra Wacana Media, 2017.

[6] Wella, "Audit Sistem Informasi Menggunakan Cobit 5.0 Domain DSS pada PT Erajaya Swasembada, Tbk," ULTIMA InfoSys, Vol. III, No.1 Juni 2016 ISSN: 2085-4579, 2016.

[7] Waluyan, Guido, dan Augie D.M., "Evaluasi Kinerja Tata Kelola TI Terhadap Penerapan Sistem Informasi Starclick Framework COBIT 5 (Studi Kasus: PT. Telekomunikasi Indonesia, Tbk Semarang)," TEKNOSI, Vol. 02, No. 03, Desember 2016 ISSN:2476 - 8812, 2016.

[8] ISACA, "A Business Framework for the Governance and Management of Enterprise IT,” Rolling Meadows:ISACA, 2012.

[9] ISACA, “Self-assessment Guide: Using COBIT® 5," Rolling Meadows:ISACA, 2012.

[10] ISACA, "COBIT Process Assessment Model (PAM): Using COBIT 5," Rolling Meadows:ISACA, 2012.

[11] ISACA, “COBIT 5: Enabling Processes," Rolling Meadows:ISACA, 2012. 